\title{
Relationship between soil water content and crop yield under sahelian climate conditions: case study of Tougou experimental site in Burkina Faso.
}

\author{
Cheick Oumar Zouré ${ }^{1}$, Mahamadou Koïta ${ }^{1 *}$, Dial Niang ${ }^{1}$, Izza Issa Baba ${ }^{1}$, Ousmane Roland \\ Yonaba ${ }^{1}$, Amagana Emmanuel Dara ${ }^{1}$, Tazen Fowé ${ }^{1}$, Pierre Queloz ${ }^{2}$ and Harouna \\ Karambiri $^{1}$ \\ ${ }^{1}$ Institut International d'Ingénierie de l'Eau et de l'Environnement, Ouagadougou, Burkina Faso, Rue de la \\ science, BP 594 Ouagadougou 01 \\ mahamadou.koita@2ie-edu.org \\ ${ }^{2}$ Environmental Engineering \& Geomatics Department, Institut of Geomatics, Environment Management, \\ Construction and Monitoring of Civil Engineering Structures (G2C), School of Engineering and Management \\ Vaud of Yverdon-les-Bains, Swiss
}

\begin{abstract}
This study aims at assessing the relationship between soil water stock and the yield of agricultural practices in Tougou catchment located in northern Burkina Faso. It is a region that has experienced a significant and continuous degradation of its natural resources, especially soils, due to the climate variability and the rapid increase of the population. Areas allocated to subsistence agriculture are increasing at the expense of pastoral land. This degradation causes a change in processes and mechanisms that control ecological systems. In order to provide solutions to this issue, some agricultural practices have been implemented to improve crop yield. This is particularly the case of traditional techniques:"zaii", "stony line" and "half-moon", which can significantly improve the soil infiltration capacity and yield. Daily monitoring of soil moisture and pressure in experimental plots based on these agricultural practices show that half-moon and Zaï provided good yield with $2180 \mathrm{~kg} / \mathrm{ha}$ and $1070 \mathrm{~kg} / \mathrm{ha}$ respectively compared to that of the control plot with about $480 \mathrm{~kg} / \mathrm{ha}$. These important yields are due in large part to the improvement of the retention capacity of these soils, thus giving to crops the necessary water need for their development even in drought periods
\end{abstract}

\section{Indexing terms/Keywords}

water content, yield, agricultural practices, crop, sahelian climate, Tougou, Burkina Faso

\section{INTRODUCTION}

For several decades, the increasing of population pressure in arid zones located in the north and south of the Sahara has led to profound changes in the management and use of natural resources and agricultural land $[1,2,3]$ These anthropogenic disturbances result in scarcity of natural vegetation, soil degradation (water and wind erosion), deterioration of the soil water regime, and a decrease in water efficiency for crop production. This has negatively affected agricultural activities in several Sahelian countries. Agricultural yields decline very significantly in this region as a result of climatic hazards and anthropogenic actions [4]. Indeed, according to the fourth report of the Intergovernmental Panel on Climate Change [5], rainfed crop yields could fall by $50 \%$ by 2020 in most of these countries. This is unfortunately the case for Burkina Faso where the situation is very pronounced in its Sahelian part. Indeed, according to the assessment provided in 1994 by the Institute for Environment and Agricultural Research of Burkina Faso (INERA) [6], about $90 \%$ of arable land in Burkina Faso Sahel is severely degraded, leading to a reduction in useful agricultural land per capita and marginal land use. In addition, the decline in annual rainfall in this region (more than 20\%) since the end of the 1960s [7] has resulted in yield reduction of cereal production of about $16-20 \%$ [8]. In this region, the degradation of soil productivity results from the unbalance of organic and mineral matter induced by repeated fires, overgrazing, clearing and cultivation. This unbalance is further accelerated by erosion, with the main consequences being a reduction of litter restitution to the soil, resulting in a decrease in the soil organic matter content and biological activities. This increases the risk of runoff, erosion and nutrient leaching, which in turn accelerates unbalance and degradation. Reducing soil's ability to store water and nutrients causes a decline in cultivation efficiency, which has become essential to maintain a porosity that is suitable for crops rooting and weeds control.

In response to these limiting factors, Sahelian farmers of Burkina Faso supported by development partners and State departments have initiated water and soil conservation techniques such as zai, stony line and half-moons $[9,10]$ to reverse the trend. These techniques have largely restored the physical, organic and chemical properties of these degraded soils, thus improving crop yields by a factor of 8 to 16 [11], restoring the efficiency of degraded soils [12] and mainly increasing household incomes [13,14]. More than $70 \%$ of farmers have adopted these agricultural techniques [15, 16, 10]. It is in this context that the present study is initiated in the Tougou experimental site and aims at establishing a relationship between the soil water content available for the root zone and yields.

\section{MATERIALS AND METHODS}

\subsection{Study Site}

The study area is the Tougou catchment (between Latitudes of $13^{\circ} 40^{\prime}$ and N, and longitudes of $2^{\circ} 13^{\prime}$ and $\mathrm{E}$ ), a surface sub-catchment of Nakambé river in the north-east of Burkina Faso. It has a surface area of $37 \mathrm{~km}^{2}$ (Figure 1). The climate is semi-arid with a mean annual rainfall of between 400 and $650 \mathrm{~mm}$. Temperatures range between 18 and $40^{\circ} \mathrm{C}$. The dry 
season extends from October to May and the rainy season from June to September with peak precipitation generally recorded in July or August. Soils are cultivated or denuded (degraded) and the vegetation consists of savanna, shrub and grassy steppe.

The site is dominated by tropical ferruginous soils leached with stains and concretions. The soil profile is composed of three main horizons. From top to bottom, we have:

- a sandy loam horizon from the top soil to $22 \mathrm{~cm}$ deep;

- a loam-clay horizon which thickness can reach $60 \mathrm{~cm}$;

- a clay horizon which thickness can reach $40 \mathrm{~cm}$.

The structure is subangular polyhedron weakly developed up to $83 \mathrm{~cm}$ deep and massive beyond.

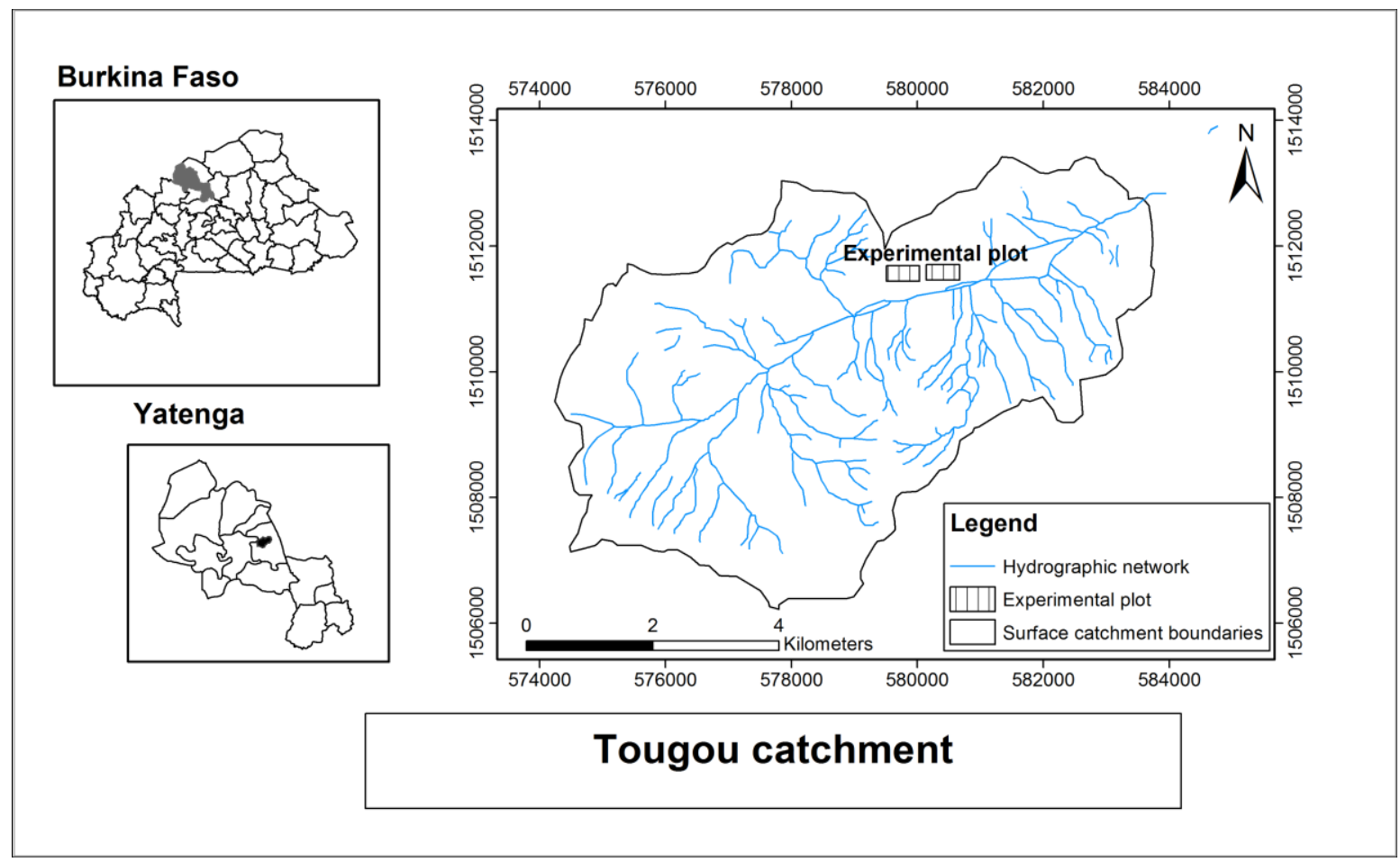

Fig 1: Location of Tougou surface catchment.

The experimental design (Figure 2) consists of two separate Fisher blocks A and B, the distribution of which is random. Each block consists of four plots of $200 \mathrm{~m}^{2}$ (20 m long by $10 \mathrm{~m}$ wide) each receiving a specific treatment (agriculture practice): direct seeding as a control plot (T0), a stony line plot (T1), a half-moon plot (T2) and a zai plot (T3):

- Control plot (T0) is without any cultivation practice where direct seeding in rows was carried out;

- Stony lines (T1) aim at reducing the runoff on the fields using a semi-permeable alignment consisting of 2 to 3 lines of polymorphic stones. These stones are arranged along topographic contour lines with a ground anchoring of 10 to $15 \mathrm{~cm}$. The average height of the alignment varies between 20 and $30 \mathrm{~cm}$ for a crest width ranging from 15 to $25 \mathrm{~cm}$. The lines are arranged perpendicular to the direction of flow;

- Half-moon is a technique consisting of semicircular holes designed for the remediation of bare land. They are arranged perpendicular to the flow and have a diameter of $4 \mathrm{~m}$. Their depth varies from 10 to $20 \mathrm{~cm}$ and the excavation is arranged in the form of a crescent at their downstream. Suitable for areas of low rainfall, they should not be implemented on hydromorphic and sandy soils

- Zai means in Mooré (local language) "to get up early and hurry to prepare one's land" or "break up and crumble the soil crust before seeding" [14,17]. This is a traditional technique implemented in Yatenga (northern Burkina Faso) from 1982 to 1984, following years of drought. It is a technique for encrusted soils remediation by digging holes 20 to $40 \mathrm{~cm}$ in diameter and 10 to $15 \mathrm{~cm}$ deep in order to collect the runoff and to infiltrate it. The cuttings are crescent-shaped downstream to capture runoff. The spacing between the zai hole is $60 \mathrm{~cm} \times 60 \mathrm{~cm}$.

An organic amendment (cow dung) of 5t/ha is applied to each plot prior to seeding and a microdose application of NPK fertilizer (2-4 g per hole) after crop emergence and urea (1 g per hole) at the run $[12,18]$. Plots are grown with a 70 -day cycle millet variety (IKMP5 Kiipalla). The choice of this variety is justified by its precocity, its resistance to drought and its wide adoption by local farmers. 


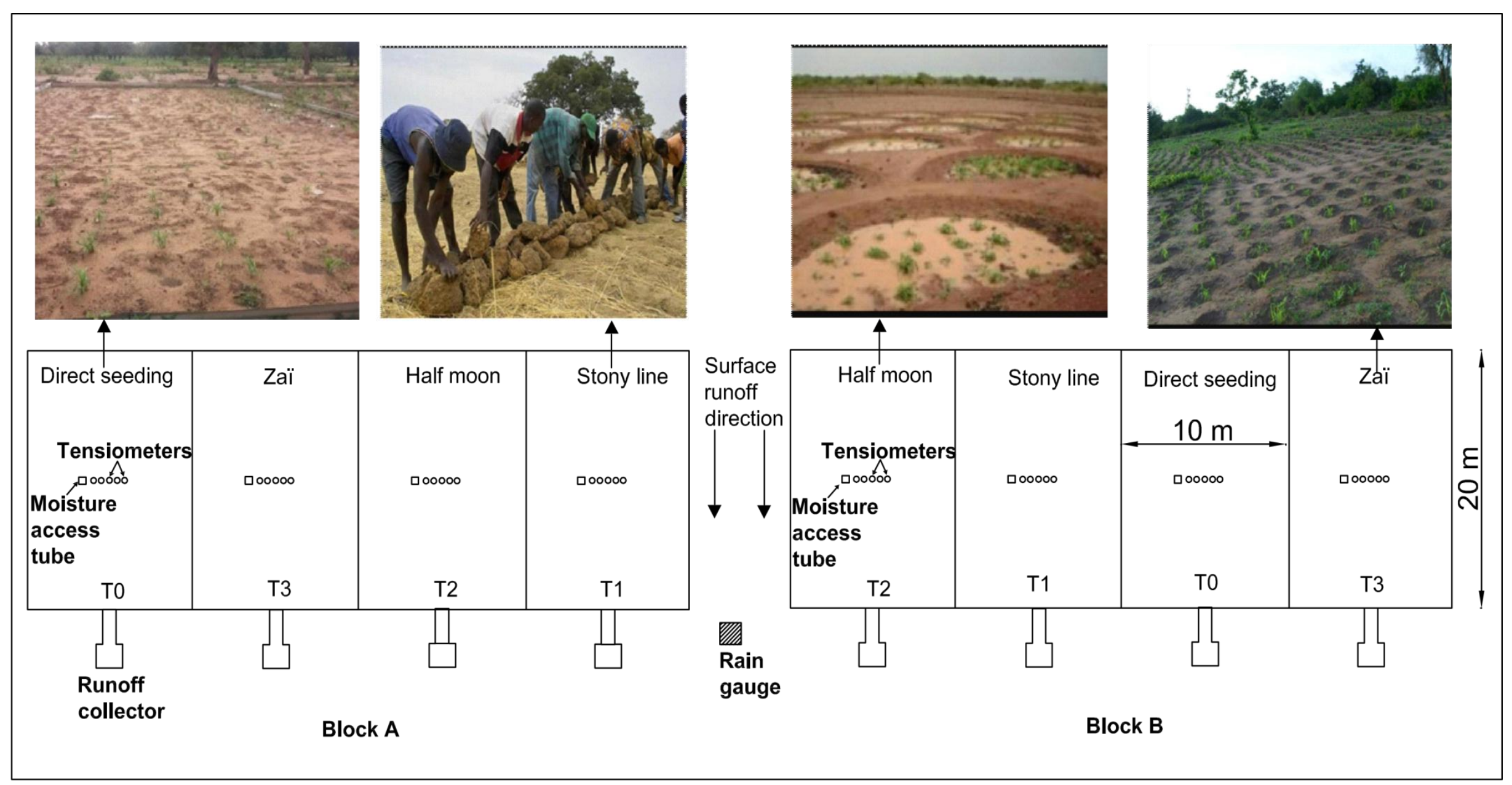

Fig 2: Plots design in Tougou experimental site 


\subsection{Field-Data Collection}

Temporal monitoring of soil moisture and soil pressure is conducted daily at 6 a.m. during field campaigns from June to October. Moisture measurements are conducted at the center of each plot; each $10 \mathrm{~cm}$ deep to $100 \mathrm{~cm}$ using a neutron probe. Pressure measurements are conducted at the same locations using tensiometers at different depths (20, 40,60, 80 and $100 \mathrm{~cm}$ ). These measurement depths correspond to root zone. Additional measurements of these two parameters are made at the end of each rainy event. Yields are determined on each plot using the yield square method.

\subsection{Data Processing}

The water content (S) available between the soil surface and $100 \mathrm{~cm}$ depth (area occupied by millet roots) is calculated from integration of the volumetric water content (equation 1):

$S_{z 2-z 1}=\int_{z 1}^{z 2} \theta d z$ (equation 1)

Where $\theta(\mathrm{cm} 3 / \mathrm{cm} 3)$ is volumetric moisture, $Z(\mathrm{~m})$ is depth.

In the present study, the water content is estimated by considering that water content measurements at depths zi (each 10 $\mathrm{cm}$ ) are representative of $10 \mathrm{~cm}$ thick layer located on both sides of the considered depth. The water content $S(\mathrm{~mm})$ at depth $\mathrm{z}$ is obtained from Equation 2:

$S_{0-z}=\left(\theta_{10} \times 100\right)+\left(\theta_{20} \times 100\right)+\left(\theta_{20} \times 100\right)+\cdots+\left(\theta_{100} \times 100\right) \quad$ (equation 2)

Change in water content $\Delta S$ in soil layer extension $\mathrm{z} 1-\mathrm{z} 2$ between two measurement dates $\mathrm{t} 1$ and $\mathrm{t} 2$ is obtained from Equation 3:

$\Delta S=S_{z 1-z 2}(t 2)-S_{z 1-z 2}(t 1)$

(equation 3)

Yields are obtained from the yield squares method which consists in placing a square randomly in the plot to determine an average yield after harvest (equation 4 ).

$R(\mathrm{~kg} / \mathrm{ha})=\frac{P(g)}{S\left(\mathrm{~m}^{2}\right)} \times 10 \quad$ (equation 4),

Where $R(\mathrm{~kg} / \mathrm{ha})$ is yield; $P(\mathrm{~g})$ is crop weight harvested in yield square and $S(\mathrm{~m} 2)$ is the square area.

In our case, three yield squares of $1 \mathrm{~m}$ side are installed on each plot and the yield is obtained as follows (equation 5):

$R m o y=\frac{1}{a} \sum_{\mathrm{i}=1}^{a} X_{\mathrm{i}} \quad$ (equation 5 ),

Where Rmean $(\mathrm{kg} / \mathrm{ha})$ is mean yield and $\mathrm{Xi}(\mathrm{kg} / \mathrm{ha})$ is yield determined in a yield square.

\section{RESULTS AND DISCUSSION}

\subsection{Results}

\section{- Soil water content}

Figure 1 shows in the different plots the temporal distribution in 2016 of the integrated water content between the surface and the depth of $100 \mathrm{~cm}$ (corresponding to root zone). In all plots, the water content remains relatively low compared to the rainfall. Indeed, the water content varies between 120 and $220 \mathrm{~mm}$ compared to the total rainfall of $424.6 \mathrm{~mm}$ with however greater differences between the plots. In the plot TOA the variation of the water content is too low and reaches a maximum value of $120 \mathrm{~mm}$ and water that has infiltrated in this plot is located in the first 50 centimeters hence it is rapidly taken off by evaporation during the days following rainy events. However, the zai and half-moon plots have higher water content (up to $220 \mathrm{~mm}$ ) that can accumulate longer in the soil. 
Plot T0A

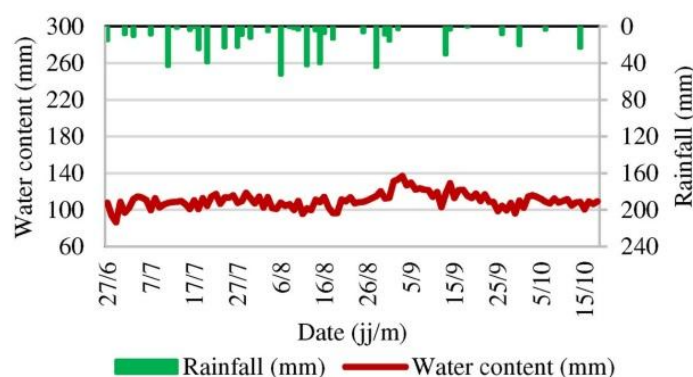

Plot T1A

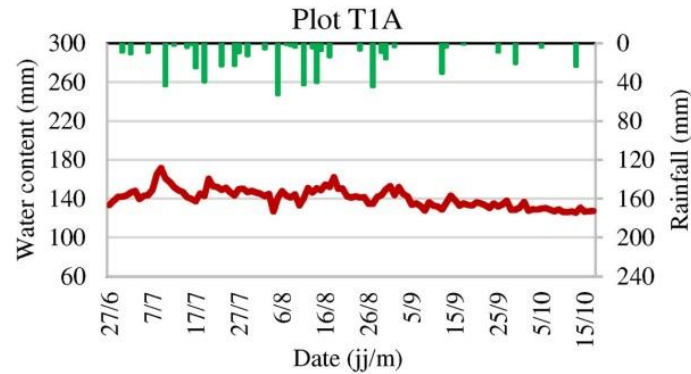

Rainfall $(\mathrm{mm}) \longrightarrow$ Water content $(\mathrm{mm})$

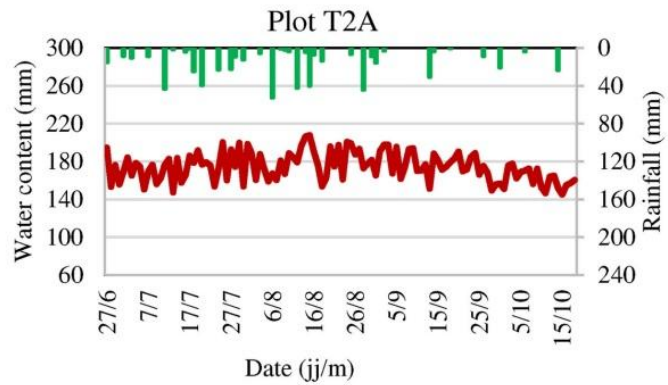

Rainfall $(\mathrm{mm}) \longrightarrow$ Water content $(\mathrm{mm})$

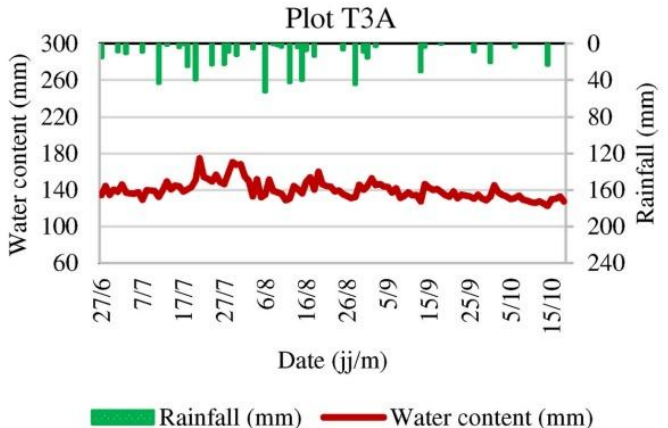

Plot T0B
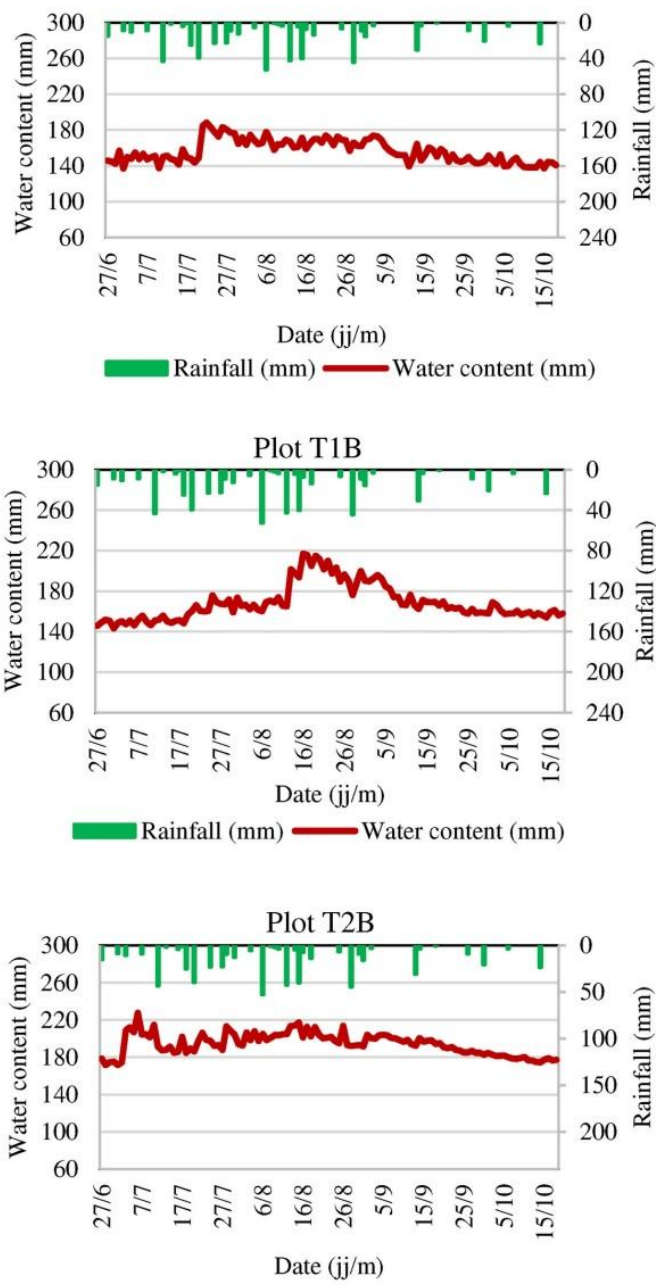

Rainfall $(\mathrm{mm}) \longrightarrow$ Water content $(\mathrm{mm})$

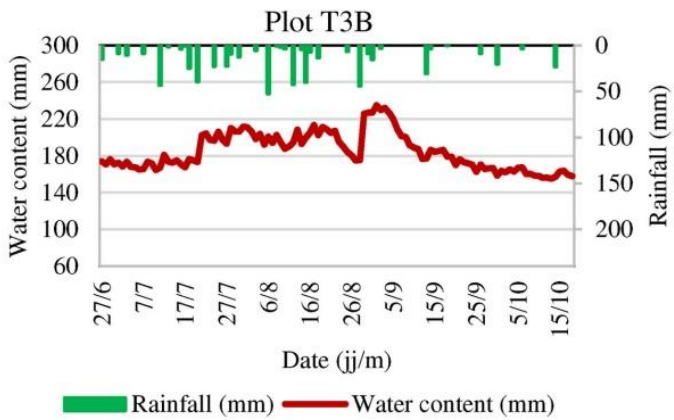

Fig 3: Temporal distribution in 2016 of the integrated water content $(\mathrm{mm})$ between soil surface and the depth of $100 \mathrm{~cm}$ in each experimental plot.

This difference in water content between the plots makes it possible to demonstrate the efficiency of the half-moon and the Zai techniques in the water storage process. These two agricultural practices by destroying soil roughness tend to increase the retention capacity with more favorable surface infiltration conditions, while for the control and stony-line plots, the surface conditions strongly influence the amount of water that will infiltrate hence the lower water content observed on these agricultural practices.

\section{- Yields}

Yield is one of the parameters that can express the performance of an agricultural production technique. The yield values of millet determined in experimental plots during the agricultural campaigns conducted in 2015 and 2016 are shown in 
Figure 2. This figure shows differences between plots. Indeed, the lowest values are found in control plots and the highest in the Zaï and half-moon plots.

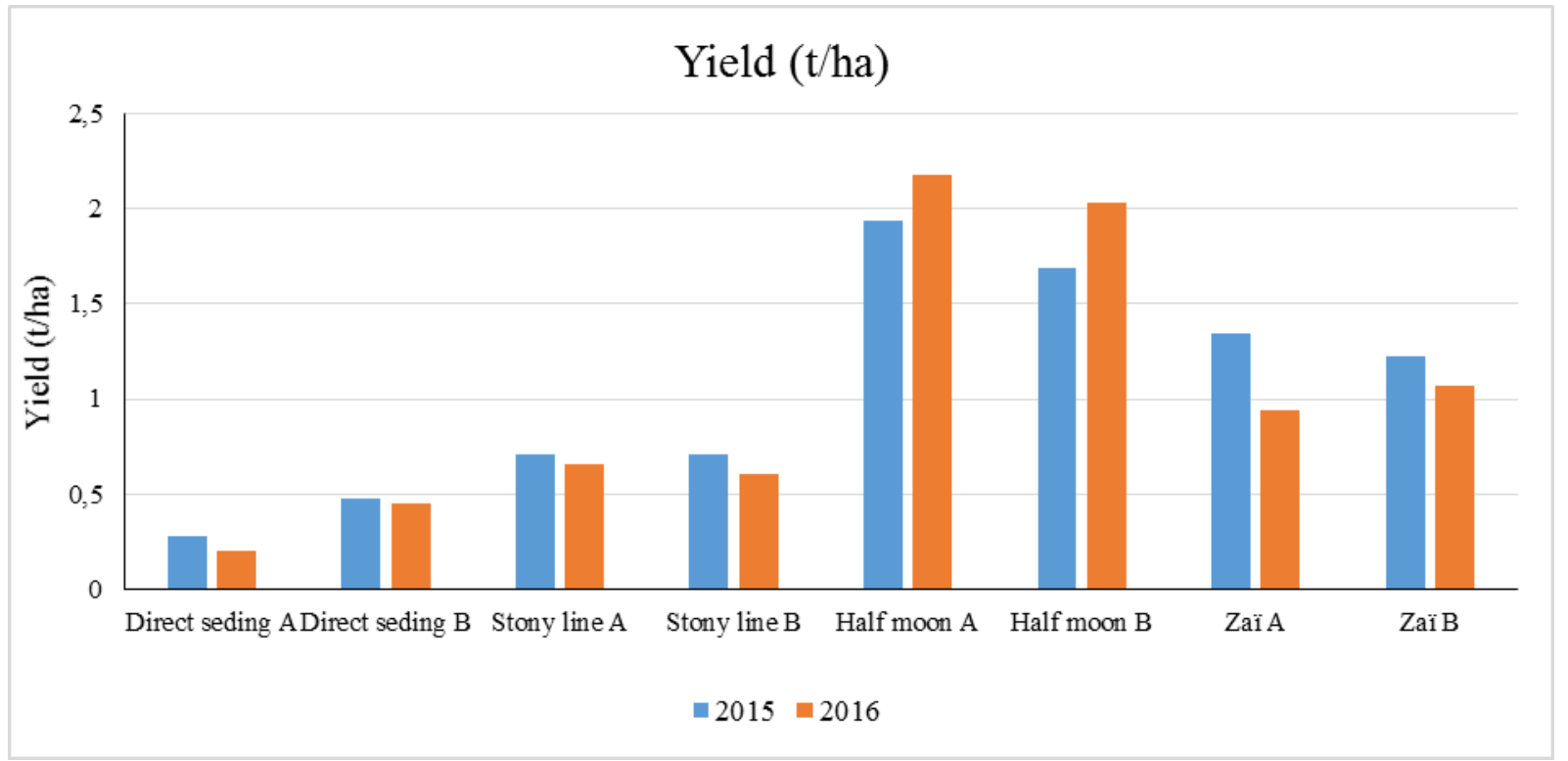

Figure 4: Yields values of millet determined in experimental plots in 2015 and 2016.

The water content and yields values determined in experimental plots during field campaign in 2016 show a positive correlation between these two parameters because the highest yields are determined in plots showing the highest water content. Indeed, the zai and half-moon plots with high water content values (220 and $240 \mathrm{~mm}$ respectively) record yields values of 1070 and $2180 \mathrm{~kg}$ per hectare respectively and the lowest yields are determined in the control and stony line plots where we note the lowest water content.

\subsection{Discussion}

Our results showed that agricultural practices such as the Zaï and the half-moon provided significant yields with 1070 $\mathrm{kg} / \mathrm{ha}$ and $2180 \mathrm{~kg} / \mathrm{ha}$ respectively. These values are higher than one of the control plot where the yield is $480 \mathrm{~kg} / \mathrm{ha}$. Harvests are much higher than the regional mean even in the year of rainfall deficit (in 2016 annual rainfall was $424 \mathrm{~mm}$ compared to an interannual mean of $600 \mathrm{~mm}$ ). This behavior of these two practices can be linked to the improvement of the soil retention capacity, thus giving to crops the necessary water need for their development even in case of severe drought pockets (more than 7 days without rain events). The digging of open holes has led to a better water infiltration into the soil and to a better water supply to exploit glacis mineral reserves. This result demonstrates the interest in the Zaï technique as a soil and water conservation practices effective in the runoff management [17]. The improvement of water availability by surface crust destruction will promote more infiltration to the soil surface resulting in more water stock available in the root zone. This high availability of water for cultivation does not mean it is the only parameter responsible for the significant increase in yields. Indeed, the removal of the physical constraint improves water conditions, but reveals other major constraints that would be linked to the soil chemical and biological poverty. Optimizing rainwater use is only of limited benefit if soil nutrient deficiency is not corrected [19]. This significant increase in yields is related to the fundamental action of organic matter summarized by Pieri [20] in three essential roles: i) it stimulates the development of crop roots; li) it is a major agent for the soil structure stability; (lii) it has a direct influence on crop nutrition and soil physicochemical properties due to its mineralization and its significance in nitrogen dynamics. According to Sedogo [21] the impact of organic matter on sorghum performance would be linked to the improvement of physico-chemical and biological properties of the soil. Zangré [22] showed that there is a strong correlation between the amount of soil organic matter, imbibition time, soil carbon content, microbial biomass, and yield. Hence the interest in a substantial contribution of organic matter if one wants to maintain a physicochemical and biological balance of the soil which favors a rapid development of cultures. These results corroborate several works carried out in the Sahel, including those of Roose et al. [23] who, following their study on rehabilitation of degraded lands in the Sudano-Sahelian region of Burkina Faso have revealed since first year that Zai on glacis allows producing 500 à $1000 \mathrm{~kg} / \mathrm{ha}$ of millet. Somé et al. [24] showed that the disappearance of glacial crusts promotes soil aeration and water retention in Zaï holes by increasing soil moisture. Concerning control and stonyline plots, the absence of organic matter landfill in the pockets has no effect on millet production on degraded soils. Indeed, surface manure spreading does not decompose in time to make mineral elements available for crops. This result could also be explained by a nitrogen deficiency situation due to competition for this element caused by microorganisms that use nitrogen for their proliferation. Zougmoré et al. [25] study showed that in decomposing this organic matter, microorganisms use mineral elements such as nitrogen, which can lead to momentary immobilization or to a lack of nitrogen in the soil limiting crops development and production. Low yields for control and stony-line plots could also be explained by low soil biological activity to decompose the manure into nutrients directly usable by crops. This observation 


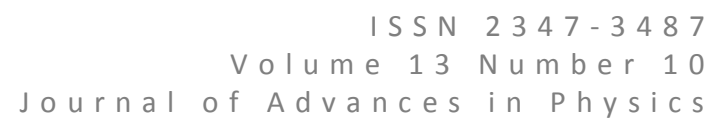

coupled with a low infiltration capacity (control plot), reveals approximatively the correlation between vegetative growth and millet yield [22] and indicates that low millet yields are due to a poor growth of crops during water stress periods.

\section{CONCLUSIONS}

The observations made in Tougou experimental plots show that the different agricultural practices are characterized by different behaviors according to the soil water content in the root zone but also to the yields. The main results show that the zaï and the half-moon present the highest water content in the root zone. This is certainly due first to the favorable conditions of infiltration created by the implementation of these two types of agricultural practices. Indeed, with these two practices, the roughness of the soil surface is destroyed thus causing more infiltration and hence a greater water availability especially during water stress periods. This high water availability also favored higher yields $(1070 \mathrm{~kg} / \mathrm{ha}$ for zaï and $2180 \mathrm{~kg} / \mathrm{ha}$ for half-moon). The increase in these yields can also come from a substantial organic matter supply directly to the crops, because with these two practices, organic matter decomposition in the soil is very easy. The results also show that low yields are obtained in control and stony-line plots due to low infiltration capacity but also to low biological activity in the soil; which allows the organic matter to decompose into nutrients directly usable by cultures.

\section{REFERENCES}

1. Maïga-Yaleu, S., Guiguemde, I., Yacouba, H., Karambiri, H., Ribolzi, O., Bary, A., Ouedraogo, R., Chaplot, V 2013. Soil crusting impact on soil organic carbon losses by water erosion. Catena, 107, pp. 26-34.

2. N'Guessan, K.A., Diarrassouba, N., Alui, K.A., Nangha, K.Y., Fofana, I.J., Yao-Kouame, A. 2015. Indicateurs de dégradation physique des sols dans le Nord de la Côte d'lvoire: cas de Boundiali et Ferkessédougou. Afrique Science: Revue Internationale des Sciences et Technologie, 11(3), pp. 115-128.

3. Reichert, J.M., Suzuki, L.E.A.S., Reinert, D.J., Horn, R., Håkansson, I. 2009. Reference bulk density and critical degree-of-compactness for no-till crop production in subtropical highly weathered soils. Soil and Tillage Research, 102(2), pp. 242-254.

4. IPCC, 2001b. Climate Change: Impacts, Adaptation, and Vulnerability. Contribution of Working Group II to the Third Assessment Report of the Intergovernmental Panel on Climate Change. Eds. Cambridge University Press, Cambridge, Royaume-Uni et New York, NY, Etats Unis d'Amérique, 1031p.

5. IPCC.2007. « Contribution du Groupe de travail III au quatrième rapport d'évaluation du Groupe intergouvernemental d'expert sur l'évolution du climat », Rapport d'évaluation, Bangkok (Thaïlande).

6. INERA 1994.. Les systèmes de production dans la zone Ouest du Burkina Faso : potentialités, contraintes, bilan et perspectives de recherche, Ouagadougou (Burkina Faso). 48p.

7. Sissoko, K., van Keulen, H., Verhagen, J., Tekken, V., Battaglini, A. 2011. Agriculture, livelihoods and climate change in the West African Sahel. Regional Environmental Change, 11 (1), pp. 119-125.

8. INSD. 2009. Annuaire statistique (2008), INSD: Ouagadougou (Burkina Faso), pp. 155-191

9. Barbier, B., Yacouba, H., Karambiri, H., Zoromé, M., Somé, B. 2009. Human Vulnerability to Climate Variability in the Sahel: Farmers' Adaptation Strategies in Northern Burkina Faso. Environmental Management, 43(5), pp. 790-803.

10. Zongo, B., Diarra, A., Barbier, B., Zorom, M., Yacouba, H., Dogot, T. 2015. Farmers' Perception and Willingness to Pay for Climate Information in Burkina Faso. Journal of Agricultural science. 8(1), p. 175

11. Amede, T., Tarawali, S., Peden, D. Zai improves nutrient and water productivity in the Ethiopian highlands (Special Issue: Improving water productivity of crop-livestock systems in drought-prone regions.). Experimental Agriculture 2011, 47(S1), pp. 7-20.

12. Sawadogo, H., Bock, L., Lacroix, D., Zombre, N.P. 2008. Restauration des potentialités de sols dégradés à l'aide du zaï et du compost dans le Yatenga (Burkina Faso). Biotechnologiy, Agronomy, Society and Environment, 12(3), pp. 279-290.

13. Zongo, B. 2016. Stratégies innovantes d'adaptation à la variabilité et au changement climatiques au Sahel: Cas de l'irrigation de complément et de l'information climatique dans les exploitations agricoles du Burkina Faso. Thèse de doctorat, Université de Liège et l'Institut International d'Ingénierie de l'Eau et de l'Environnement, Liège (Belgique).

14. Zougmoré, R., Ouattara, K., Mando, A., \& Ouattara, B. 2004b. Rôle des nutriments dans le succès des techniques de conservation des eaux et des sols (cordons pierreux, bandes enherbées, zaï et demi-lunes) au Burkina Faso. Science et changements planétaires/Sécheresse, 15(1), pp. 41-48.

15. Drechsel, P., Olaleye, A., Adeoti, A., Thiombiano, L., Barry, B., Vohland, K. 2005. Adoption driver and constraints of resource conservation technologies in sub-Saharan Africa. Berlin: FAO, IWMI, Humbold Universitaet, pp 1-21

16. Kpadonou, R.A.B., Owiyo, T., Barbier, B., Denton, F., Rutabingwa, F., Kiema, A. 2017. Advancing climate-smartagriculture in developing drylands: Joint analysis of the adoption of multiple on-farm soil and water conservation technologies in West African Sahel. Land Use Policy, 61, pp. 196-207. 

production végétale des sols dégradés (zippella) du Burkina Faso par la technique des poquets (Zaï). Thèse essciences $n^{\circ} 1302$ (1994), Ecole Polytechnique Fédérale de Lausanne, Lausane (Suisse).

18. Zougmoré, R., Mando, A., Stroosnijder, 2004a. L. Effect of soil and water conservation and nutrient management on the soil-plant water balance in semi-arid Burkina Faso. Agricultural Water Management 65(2), pp. 103-120.

19. Roose, E. 1994. Introduction à la gestion conservatoire de l'eau, de la biomasse et de la fertilité des sols (GCES). Bulletin Pédologique FAO, n70, $420 \mathrm{p}$.

20. Pieri, C. 1989 Fertilité des terres de savane. Bilan de trente ans de recherche et de développement agricole au sud du Sahara. Ministère de la Coopération et du Développement (CIRAD) Montpelier, France. 444 p. ISBN : 287614-024-1

21. Sedogo, P.M. 1993. Evolution des sols ferrugineux lessivés sous culture : incidence des modes de gestion sur la fertilité. Thèse de doctorat, Université de Cocody, Abidjan (Côte d'ivoire).

22. Zangré, B.V.C.A. 2000. Effets combinés du travail du sol et des amendements organiques sur la fertilité d'un sol ferrugineux tropical lessivé dans la région de Saria (zone centre du Burkina Faso), Mémoire, IDR.

23. Roose, E., Kabore, V., Guenat, C. 1995. Le zaï: fonctionnement, limites et améliorations d'une pratique traditionnelle africaine de réhabilitation de la végétation et de la productivité des terres dégradées en région soudano-sahélienne (Burkina Faso). Cahier ORSTOM Pédologie. 28(2), pp. 159-173

24. Somé, L., Hien, V., Bilgo, A., Sangaré, S., Karambiri, L., Kaboré, P., Lepage, M., Traoré, J., Somé, B., and Traoré, K. 2004. Rapport du projet de de lutte contre la désertification au Sahel et étude de leur impact agro écologique, INERA, Kamboinse (Burkina Faso), 91p.

25. Zougmoré, R., Zida, Z. and Kambou, F.N. 1999. Réhabilitation des sols dégradés: Rôles des amendements dans le succès des techniques de Demi-lune et de Zaï au Sahel. Bulletin du Réseau Erosion, 19, pp. 436-450.

This work is licensed under a Creative Commons Attribution 4.0 International License. 